ISSN : 2303-1514 | E-ISSN : 2598-5949

\title{
TEACHERS' ROLE IN BUILDING THE CHARACTER OF CONFIDENCE IN ONLINE-BASED THEMATIC LEARNING
}

\author{
Eka Putri Martiyana ${ }^{1^{*}}$, Ujang Jamaludin ${ }^{2}$, Ikman Nur Rahman ${ }^{3}$ \\ ${ }^{1,2,3}$ Universitas Sultan Ageng Tirtayasa, Serang, Banten \\ I*ekaputrimartiyana@gmail.com
}

\section{PERAN GURU DALAM MENANAMKAN KARAKTER PERCAYA DIRI PADA PEMBELAJARAN TEMATIK BERBASIS DARING}

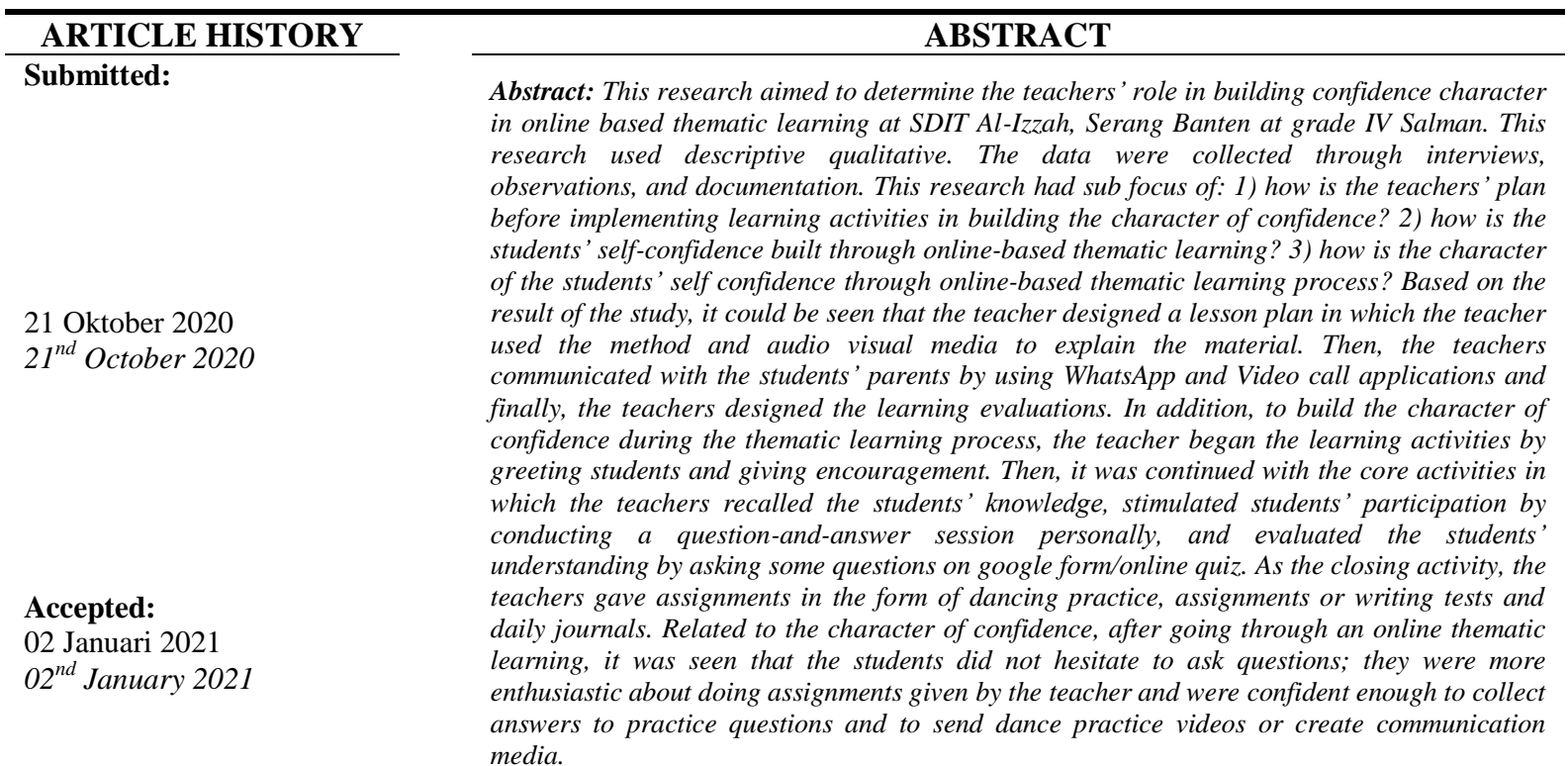

Keywords: Teachers' Role, Character Of Confidence, Thematic Learning

Published:

20 Februari 2021

$20^{\text {nd }}$ February 2021
Abstrak: Penelitian ini memiliki tujuan untuk mengetahui peran guru dalam menanamkan karakter percaya diri pada pembelajaran tematik berbasis daring di SDIT Al-Izzah, Serang Banten tepatnya pada kelas IV Salman. Penelitian ini menggunakan jenis penelitian kualitatif deskriptif. Teknik pengumpulan data yang digunakan yaitu wawancara, pengamatan dan dokumentasi. Pada penelitian ini memiliki sub fokus, 1) Bagaimana perencanaan guru sebelum melaksanakan kegiatan pembelajaran dalam menanamkan karakter percaya diri? 2) Bagaimana proses penanaman karakter percaya diri siswa melalui pembelajaran tematik secara daring? 3) Bagaimana karakter percaya diri siswa melalui proses pembelajaran tematik secara daring?. Berdasarkan hasil penelitian dapat diketahui bahwa guru merancang rencana pembelajaran yang didalamnya guru menggunakan metode, guru menggunakan media audio visual dalam menjelaskan materi, guru menjalin komunikasi dengan orang tua siswa maupun siswa menggunakan aplikasi WhatsApp dan Video call serta guru merancang evaluasi pembelajaran. Kemudian dalam menanamkan karakter percaya diri pada saat proses pembelajaran tematik yaitu guru melakukan kegiatan awal pembelajaran dengan menyapa siswa, memberikan semangat sebelum pembelajaran daring dimulai. Kemudian dilanjut dengan kegiatan inti yang dimana guru menggali pengetahuan siswa, menstimulus keaktifan siswa dengan cara membuka sesi tanya jawab secara personal chat, menguji pemahaman siswa dengan tanya jawab dapat berupa soal maupun pertanyaaan di google form/quiz online. Pada kegiatan penutup guru memberikan tugas berupa praktik menari, penugasan ataupun tes tulis dan jurnal harian. Karakter percaya diri siswa setelah melalui proses pembelajaran tematik secara daring yang dimana guru menyatakan bahwa siswa tampak aktif dalam pembelajaran daring, siswa tidak sungkan untuk bertanya, siswa antusias mengerjakan tugas 
Kata Kunci: Peran Guru, Karakter Percaya Diri, Pembelajaran Tematik

\section{CITATION}

Martiyana, E. P., Jamaludin, U., \& Rahman, I. U. (2021). Teachers' Role in Building the Character of Confidence in Online-Based Thematic Learning. Primary: Jurnal Pendidikan Guru Sekolah Dasar, 10 (1), 79 - 93. DOI: http://dx.doi.org/10.33578/jpfkip.v10i1.8076.

\section{PENDAHULUAN}

Setiap individu yang lahir memiliki kemampuan masing-masing yang beranekaragam. Kemampuan tersebut perlu dikembangkan agar mendatangkan manfaat untuk diri sendiri maupun orang lain. Untuk mengeksplor kemampuan yang dimiliki, diperlukan rasa percaya diri yang timbul dalam diri manusia. Selain itu, dalam menghadapi masalah atau suatu hal yang baru juga diperlukan keyakinan dalam diri dan rasa optimis untuk menyelesaikan masalah tersebut. Hal tersebut senada dengan pendapat (Hambly, 1995: 3) yang dikutip kembali oleh Henny puspitarini (2013:49) suatu bentuk keyakinan akan diri sendiri dalam mengerjakan, menghadapi persoalan, masalah serta menjalankan sesuatu tanpa ada ketakutan ataupun kecemasan pada dirinya itulah yang disebut percaya diri. Dalam kehidupan seharihari juga membutuhkan interaksi sosial dengan orang lain dan membutuhkan rasa percaya diri untuk mengungkapkan sesuatu atau menyampaikan pesan/informasi kepada lawan bicara. Menurut Derry Iswidharmanjaya dan Jubilee Enterprise (2014:49) mengungkapkan bahwa seseorang yang percaya diri akan mudah dalam berinteraksi dan mudah bergaul dengan siapapun, dapat mengungkapkan pesan yang ingin disampaikan kepada orang lain serta timbul rasa yakin jika diberi amanah/peran. Salah satu cara untuk menanamkan rasa percaya diri dapat melalui pendidikan informal, formal maupun non formal, Pendidikan sendiri mempunyai makna yaitu suatu kegiatan yang dimana dapat mengembangkan kemampuan serta menambah wawasan ilmu pengetahuan. Dalam pendidikan akan terjadi sebuah proses belajar dari hal yang tidak tahu menjadi tahu, dari hal yang tidak bisa menjadi bisa, mengasah keterampilan siswa, menambah ilmu pengetahuan, berproses menjadi pribadi yang berkarakter. Pemaparan di atas, berkaitan dengan definisi pendidikan menurut UU No. 22 Tahun 2003 tentang SISDIKNAS yang dimana dituliskan bahwa pendidikan adalah usaha sadar dan terencana untuk mewujudkan suasana belajar dan proses pembelajaran agar peserta didik secara aktif mengembangkan potensi dirinya untuk memiliki kekuatan spiritual keagamaan, pengendalian diri, kepribadian, kecerdasan, akhlak mulia, serta keterampilan yang diperlukan dirinya, masyarakat, bangsa, dan negara.

Dalam proses pembelajaran, guru dapat menanamkan karakter percaya pada siswa. Misalnya, melalui tanya jawab, mengungkapkan pendapat ataupun bercerita tentang pengalamannya. Banyak hal yang dapat dilakukan oleh guru agar karakter percaya diri siswa tumbuh melekat dalam dirinya. Namun, tidak sedikit siswa yang masih merasa malu atau tidak percaya diri terhadap kemampuan yang dimiliki. Kemungkinan disebabkan adanya faktor internal maupun eksternal yang membuat siswa merasa kurang percaya diri. Salah satu upaya pemerintah dalam melakukan penguatan karakter pada insan penerus bangsa ini yaitu dengan menyelenggarakan penguatan karakter sebanyak $70 \%$ dan $60 \%$ dilakukan pada jenjang sekolah menengah. Peran pemerintah dan pihak sekolah beserta jajarannya untuk 
terus berusaha mengedepankan pendidikan karakter melalui kerja sama antar pemerintah, sekolah dan guru. Serta terus memantau perkembangan siswa. Dikarnakan faktor perusak karakter pada diri siswa sangatlah banyak, seperti faktor lingkungan dan teknologi.

Penelitian ini dilakukan di SDIT AlIzzah, Serang Banten tepatnya di kelas IV. Dalam studi pra penelitian yang peneliti lakukan, guru mengungkapkan bahwa dalam pembelajaran siswa merasa pesimis dengan teman-teman lainnya yang memiliki kemampuan atau pengetahuan yang lebih dalam belajar, sehingga muncul rasa ketidakpercayaan diri siswa. pada saat proses pembelajaran sering kali melihat siswa yang merasa malu untuk bertanya terkait ketidakpahaman materi, menjawab pertanyaan guru, bahkan melontarkan pendapatnya. Dari sekian jumlah siswa 20 orang perkelas, hanya 4 atau 5 siswa saja yang memiliki keberanian untuk menunjukkan kepercayaan dirinya dalam kegiatan belajar mengajar. Melihat hal tersebut, apabila kepercayaan diri tidak muncul dalam diri siswa, maka kemungkinan siswa kurang aktif dalam proses kegiatan pembelajaran terkhususnya pada saat siswa berbicara atau mengungkapakan pendapat/ide di depan guru dan teman-temannya. Melihat hal tersebut sebagai guru perlu mengasah kepercayaan diri dan siswa juga perlu melatih dirinya untuk menjadi pribadi yang tidak malumalu dalam melakukan proses pembelajaran, dikarenakan siswa dituntut untuk belajar aktif dan antusias dalam mengikuti pembelajaran. Maka peran guru sangat diperlukan dalam mengoptimalkan penanaman nilai karakter khususnya pada karakter percaya diri. Dikarnakan karakter percaya diri perlu ditanamkan pada diri siswa agar kelak siswa memiliki rasa percaya diri terhadap diri sendiri, dan mampu mengeksplor kemampuan diri pada lingkungan sekitar. Hal tersebut, tidak lepas dari dorongan maupun motivasi dari seorang guru maupun orang terdekat siswa. Maka dengan peran guru dapat membantu siswa menjadi pribadi yang percaya diri sehingga kepercayaan diri siswa perlahan akan muncul dan terus berkembang, dan pada akhirnya siswa memiliki rasa percaya diri dimanapun dan kapanpun.

\section{KAJIAN TEORI}

\section{A. Peran Guru}

Peran guru sendiri memiliki pengertian dari beberapa pendapat ahli, Prey Katz dalam (Sardiman A.M, 2014:143), menurutnya guru sebagai sahabat dalam memberi nasihat, pemberi inspirasi serta dorongan, komunikator, seseorang yang menguasai bahan ajar, dan pembimbing dalam mengembangkan sikap, tingkah laku serta nilai-nilai. Semua itu merupakan gambaran peran seorang guru. Kemudian Havighurst dalam (Sardiman A.M, 2014:143-144), memaparkan bahwa peran guru di sekolah merupakan bawahan (subordinate) dari atasannya, pegawai dalam ruang lingkup kedinasan, sebagai mediator yaitu penghubung antara guru dengan peserta didik, selaku penegak disiplin, pengganti orang tua di sekolah, evaluator, dan sebagai kolega antar teman sejawat. Sedangkan menurut James W. Brown dalam (Sardiman A.M, 2014:144), menjelaskan bahwa guru mempunyai peranan serta tugas sebagai berikut: memahami, menguasai dan dapat mengembangkan materi pelajaran, merekareka serta mempersiapkan pelajaran sehariharinya, memantau dan menilai kegiatan siswa selama proses pembelajaran. Berdasarkan penjelasan menurut beberapa ahli di atas, dapat diberi kesimpulan bahwa peran guru tidak hanya mendidik dan membimbing siswa saja, namun peran pendidik berkaitan dengan pengetahuan, sikap dan keterampilan siswa yang dimana peran guru penting untuk membangun serta mengembangkan kemampuan yang siswa miliki. Tidak hanya itu peran guru sebagai fasilitator, mediator, motivator maupun penggerak proses pembelajaran selama di sekolah. Peranan guru sebagai media penghubung antara siswa dan orang tua siswa, sebagai penasihat, 
mengembangkan sikap baik yang dimiliki siswa. Selain itu guru juga berperan untuk mempersiapkan pembelajaran, guru harus menguasai bahan ajar dan kelas selama pembelajaran daring maupun luring, merancang evaluasi pembelajaran, merancang kegiatan selama ada pandemi dan guru sebagai orang tua pengganti selama siswa di sekolah.

\section{B. Pengertian Karakter}

Setiap individu memiliki karakter atau sifat yang berbeda-beda dalam menyikapi atau menghadapi kondisi tertentu. Memiliki karakter atau sifat yang baik akan mendatangkan kebaikan bagi diri sendiri maupun orang lain lain serta tidak merugikan orang disekitarnya. Karakter dapat muncul dalam diri seseorang yaitu dapat berasal dari keturunan orang tua atau bahkan pengaruh dari lingkungan hidup. Dengan begitu karakter merupakan cerminan dari diri kita sendiri. Dalam Ameican Herritage Dictionary, karakter merupakan ciri, atribut, kualitas sifat. Dengan demikian kemampuan yang dimiliki individu merupakan pembeda dengan individu yang lain. Disamping itu menurut KBBI karakter memiliki arti yaitu budi pekerti, sifat kejiwaan atau akhlak yang dimana sebagai pembeda dengan orang lain. Sedangkan menurut Gordon W. Allport dalam Sri Narwanti (2014:2) karakter merupakan tingkah laku dan pemikiran individu yang berasal dari system psiko-fisik individu tersebut. Dengan begitu, dapat disimpulkan bahwa karakter merupakan tingkah laku/tabiat/watak/sifat seseorang yang berbeda dengan individu lainnya dan menjadikan suatu kekhasan dalam diri setiap individu.

\section{Pengertian Percaya Diri}

Percaya diri yaitu suatu sikap yang dapat mendorong dirinya untuk mempercayai skill atau kemampuan yang dimiliki. Sikap percaya diri juga merupakan bentuk keyakinan atas sesuatu yang dilakukan oleh dirinya dalam melakukan atau menghadapi sesuatu. Menurut Mohamad Mustari (2014) Percaya diri adalah merasa yakin atas kemampuan dirinya sendiri pada sesuatu yang ingin dicapai dan diharapkan. Menurut (Hambly, 1995: 3) yang dikutip kembali oleh Henny Puspitarini (2013:49) suatu bentuk keyakinan akan diri sendiri dalam mengerjakan, menghadapi persoalan, masalah serta menjalankan sesuatu tanpa ada ketakutan ataupun kecemasan pada dirinya itulah yang disebut percaya diri. Menurut Menurut Hassan, dkk dalam Derry Iswidharmanjaya dan Jubilee Enterprise (2014:20) percaya diri merupakan kepercayaan yang sudah tertanam pada diri serta dapat memanfaatkan kemampuan yang dimiliki untuk mencapai sesuatu yang diinginkan. Dapat ditarik kesimpulan yakni percaya diri merupakan kemampuan yang datang dari diri sendiri dan hanya diri sendirilah yang dapat mendatangkan rasa percaya diri itu sendiri berupa keyakinan yang kuat, perilaku dengan penuh keyakinan, menyadari kemampuan yang dimilikinya serta motivasi yang tinggi.

\section{METODE PENELITIAN}

Penelitian ini dilakukan di SDIT AlIzzah, Serang Banten pada bulan November 2019 sampai dengan bulan Oktober 2020. Subjek dari pada penelitian ini yaitu guru kelas IV Salman yang bernama Laila Uswatunnisa, S.Si., M.Pd. dan Eneng Novalia Haris, S.Pd.I., M.Pd. selaku Waka Kurikulum. Metode penelitian menggunakan metode kualitatif deskriptif yaitu metode yang menggambarkan atau menjelaskan fenomena yang terjadi di lapangan selama penelitian. Pengumpulan data pada penelitian ini menggunakan pengamatan, wawancara dan dokumentasi. Peneliti menggunakna analisis data dari Miles dan Huberman berikut di bawah ini: 


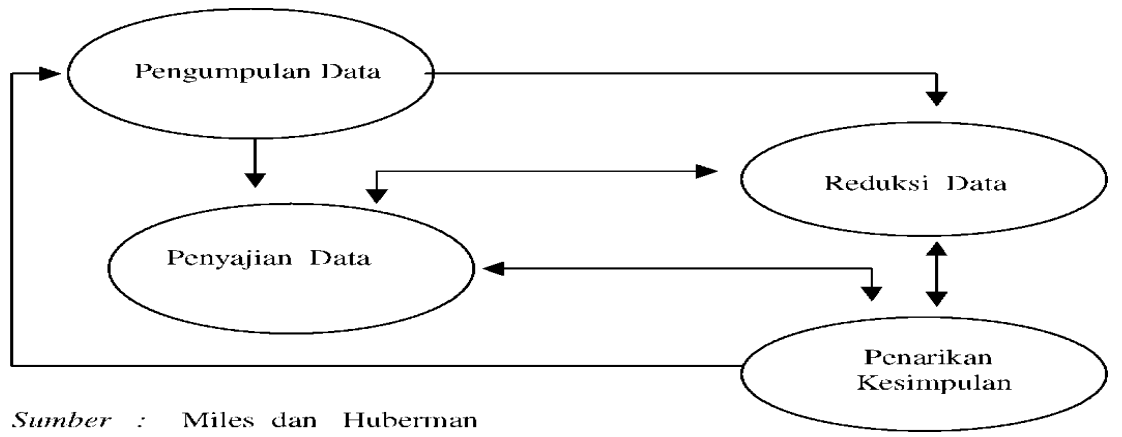

Gambar 1. Langkah-langkah Penelitian

Untuk pemeriksaan keabsahan data meliputi uji kredibilitas/validitas penelitian menggunakan triangulasi data, diskusi dengan teman sejawat., uji transferabilitas yaitu sejauh mana hasil penelitian dapat diterapkan atau dimanfaatkan di situasi/tempat lain. Kemudian uji dependabilitily yang merupakan pengecekan terhadap seluruh proses penelitian, uji conformability merupakan bentuk konfirmasi hasil penelitian dengan proses penelitian yang telah dilakukan. Berikut di bawah ini panduan instrumen penelitian yang telah peneliti rancang:

\section{HASIL DAN PEMBAHASAN}

\section{A. Perencanaan Guru Sebelum Melaksanakan Kegiatan Pembelajaran dalam Menanamkan Karakter Percaya Diri \\ Pada penelitian ini, peneliti telah} melakukan penelitian di SDIT Al-Izzah Serang, Banten pada kelas IV Salman, pada penelitian ini peneliti ingin mengetahui peran guru dalam menanamkan karakter percaya diri pada pembelajaran tematik berbasis daring. Dalam proses belajar mengajar yang guru lakukan tidak lepas dari peran seorang guru dalam memberi arahan dan mendidik selama proses pembelajaran, sebagai fasilitator dan motivator. Guru tampak menunjukkan peranan sebagai guru pada saat pembelajaran seperti halnya menjelaskan materi dalam bentuk video, memberi motivasi untuk terus semangat belajar, sebagai fasilitator, evaluator dan lain- lain. Pemaparan sebelumnya berkenaan dengan teori dari Hosnan (2016:22) Guru berperan untuk memberikan pemahaman melalui penjelasan materi, mendidik, membina, motivasi atau dorongan untuk terus bersemangat dalam belajar. Selain itu pandangan menurut Sanjaya (2006:37-64) dalam (Jamaludin, dkk. 2018:51) yakni guru sebagai pembimbing, evaluator, memiliki kreativitas, mendidik siswa, memimpin serta menguasai kelas, konselor bagi anak serta motivator. Sedangkan pandangan menurut Adam dan Decery dalam (Jamaludin, dkk. 2018:51) menggambarkan bahwa guru berperan sebagai mediator serta fasilitator dalam belajar mengajar, pengelola kelas, perencana sekaligus pelaksana, evaluator, motivator, administrator, pemberi reward dan pengajar yang baik. Selain peranan guru yang dibutuhkan selama proses pembelajaran daring, guru juga perlu mempersiapkan rancangan pembelajaran agar semua kegiatan pembelajaran berjalan dengan lancar.

Sebelum guru IV Salman melaksankan pembelajaran, beliau mempersiapkan rancangan pembelajaran terlebih dahulu agar pembelajaran yang guru lakukan dapat terarah dan mencapai tujuan pembelajaran. Walaupun pembelajaran dilakukan secara daring, guru tetap membuat rencana pembelajaran. Rencana pembelajaran tetap sama seperti biasanya tidak ada perubahan walaupun pembelajaran dilakukan dalam jaringan. Hal tersebut sependapat dengan Rusman (2014:75) yang menjelaskan bahwa sebelum melaksanakan 
kegiatan pembelajaran, guru diharuskan membuat rancangan pembelajaran dan menguasai bahan ajar. Kemampuan guru dalam mengajar dapat ditinjau dari rancangan ataupun proses penyusunan program kegiatan pembelajaran yang akan digunakan guru pada saat mengajar. Rancangan pembelajaran merupakan turunan dari silabus, yang kemudian di spesifikan ke dalam RPP. Sedangkan Menurut Hosnan (2016:96-100) mengungkapkan bahwa RPP dibuat untuk tatap muka maupun dalam jaringan untuk satu kali pertemuan atau lebih agar guru terarah dan tersampaikan tujuan yang ingin guru capai dalam mengajar. RPP merupakan hasil kembangan dari silabus sebagai upaya mencapai kompetensi dasar. Unsur-unsur RPP yaitu identitas sekolah, identitas mata pelajaran, kelas/semester, alokasi waktu, kompetensi inti, kompetensi dasar dan indikator pencapaian kompetensi, tujuan pembelajaran yang menggunakan kata kerja operasional, materi pokok, model pembelajaran, metode pembelajaran, media pembelajaran, langkah-langakah kegiatan pembelajaran yang berisi kegiatan pendahuluan, kegiatan inti, kegiatan penutup, sumber belajar, dan evaluasi pembelajaran (Hosnan, 2016:96-100).

Di dalam unsur-unsur RPP terdapat metode pembelajaran yang guru gunakan pada saat mengajar agar pembelajaran yang guru lakukan tidak membosankan. Metode pembelajaran adalah cara guru dalam mengajar selama proses pembelajaran (Jamaludin, 2020:63). Maka dengan menggunakan metode yang bervarisi dapat diartikan bahwa guru mempunyai cara yang unik dalam proses pembelajaran. Guru IV Salman tetap menggunakan metode namun metode yang digunakan lebih kepada ceramah, tanya jawab dikarnakan pembelajaran yang bersifat daring. Hal tersebut sesuai dengan pendapat Rusman (2014:75) Guru mampu menggunakan metode pembelajaran dan memilih metode yang tepat sesuai dengan materi yang akan diajarkan. Sebab siswa senang dengan kegiatan pembelajaran yang bervariasi, maka dari itu guru hendaknya melakukan metode pembelajaran yang bervariasi agar siswa tidak bosan dalam belajar. Selain metode adapun media pembelajaran yang guru gunakan selama mengajar. Penggunaan media pembelajaran bertujuan untuk memudahkan siswa dalam memahami materi pembelajaran dan memancing keaktifan siswa dalam pembelajaran. Hal tersebut senada dengan pendapat Adam dan Syastr (2015) dalam (Jamaludin, 2020:66) yang menyatakan bahwa media merupakan sesuatu yang berbentuk fisik ataupun visual yang dapat membantu guru menyampaikan materi dan memudahkan siswa memahami materi yang disampaikan guru, maka akan mudah tercapai tujuan pembelajaran. Media yang guru gunakan lebih kepada media audio visual karena penyampaian materi lewat media gambar atau video pembelajaran agar dapat disimak oleh siswa melalui laptop maupun handphone. Media yang digunakan oleh guru merupakan media audio visual yang dimana media tersebut menampilkan gambar dan menghasilakan suara (Jamaludin, 2020:66). Kemudian didukung oleh Rusman (2014) yang menyatakan bahwa Penggunaan media sebagai alat bantu guru dalam mengajar sehingga siswa akan mudah dalam memahami materi pelajaran dan didukung pula oleh R. Ibrahim dan Nana Syaodih S dalam Rusman (2014) Media pembelajaran digunakan untuk merangsang siswa berpikir, perhatian siswa, menyalurkan pesan yang ingin disampaikan guru dan memancing kemampuan siswa dalam proses pembelajaran.

Dikarnakan pembelajaran di lakukan secara daring, maka guru perlu menjali komunikasi yang baik dengan orang tua agar tidak ada miskomunikasi antara guru dan orang tua siswa. Menjalin komunikasi yang baik bagian dari peran sebagai guru yang baik. Hal tersebut diungkapkan oleh Sardiman A.M (2014:143) bahwa guru sebagai komunikator bagi siswa dan orang tua siswa. Maka dapat dijelaskan bahwa guru juga menjalin 
komunikasi yang baik dengan orang tua siswa sehingga pembelajaran yang dilakukan secara daring tetap tersampaikan kepada siswa secara baik dan jelas. Komunikasi yang baik antara guru dan siswa merupakan hal yang sangat penting, karena agar terwujudnya pembelajaran yang efektif. Tidaklah mungkin pembelajaran akan berjalan dengan lancar jika tidak diiringi dengan komunikasi yang baik antara guru dan siswa. Bahasa yang digunakan dalam berkomunikasi tidak hanya menggunakan bahasa tulisan/lisan namun bisa menggunakan, seperti gerak gerik tubuh, bahasa isyarat, emoticon dan lain-lain. Hal di atas senada dengan pemaparan menurut Masdul (2018:3) Pembelajaran dapat dikatakan berhasil dan berjalan lancar jika komunikasi yang terjalin selama pembelajaran cukup efektif. Kemudian dijelaskan kembali pada saat pembelajaran, komunikasi antara pendidik dan peserta didik memiliki hubungan yang selaras atau harmonis, maka komunikasi selama pembelajaran tergantung pada dua belah pihak. (Masdul, 2018:5). Melihat dari segi prosesnya, komunikasi dibagi menjadi tiga jenis yaitu secara verbal dan non verbal menurut Masdul (2018:6) yaitu Komunikasi secara verbal merupakan komunikasi yang menggunakan Bahasa secara lisan ataupun tertulis. Kemudian komunikasi secara non verbal yaitu komunikasi berbentuk gambar, isyarat, mimik muka, gerak gerik dan lain sebagainya. Guru kelas IV Salman menjalin komunikasi dengan para orang tua siswa menggunakan aplikasi WhatsApp secara daring, sehingga apapun yang berkaitan dengan pembelajaran dan sekolah disampaikan lewat grup atau personal chat via aplikasi WhatsApp. Hal di atas menerangkan secara jelas bahwa komunikasi yang terjadi selama pembelajaran untuk memulai proses interaksi selama pembelajaran, karena tidak akan terjadi kegaitan pembelajaran tanpa adanya interaksi atau komunikasi antara dua belah pihak atau lebih.

Setelah guru menyampaikan materi pembelajaran dan berkomunikasi aktif antar sesama, guru akan memberikan soal evaluasi kepada siswa untuk mengetahui pemahaman siswa terhadap materi yang telah guru sampaikan. Soal evaluasi yang guru berikan dapat berupa soal latihan, praktik dan lain sebagainya agar tujuan pembelajaran tercapai. Pemaparan tersebut senada dengan pendapat Rusman (2014) Guru mampu mengevaluasi siswa setelah kegiatan pembelajaran. Guru dapat memberikan soal latihan untuk mengetahui tercapainya tujuan pembelajaran dan tingkat pemahaman siswa terhadap materi yang disampaikan guru. Pada tahapan ini guru memiliki tuntutan untuk merancang evaluasi pembelajaran, mengelola hasil evaluasi. Dengan begitu, guru kelas IV Salman memberikan soal evaluasi melalui WhatsApp atau link google foam. Setelah siswa selesai mengerjakan tugas, siswa dapat mengumpulkan tugas secara personal chat dengan cara di foto atau diisi langsung pada link google foam.

\section{B. Proses Penanaman Karakter Percaya Diri Siswa Melalui Pembelajaran Tematik Secara Daring \\ Situasi pembelajaran saat ini} mengharuskan guru untuk berfikir agar pembelajaran tetap berjalan dengan baik dan lancar. Maka pihak sekolah dan guru terus merancang dan memperbaiki sistem pembelajaran daring yang sedang berjalan. Dengan kondisi pembelajaran yang dilakukan serba daring, membuat peneliti melakukan pengamatan kepada guru dengan cara bertanya terkait proses penanaman karakter percaya diri siswa melalui pembelajaran tematik secara daring yang dimana seharusnya peneliti amati secara langsung. Pengamatan yang peneliti lakukan kepada guru kelas IV Salman yaitu ibu Laila Uswatunnisa, S.Si., M.Pd. Beliau menjelaskan bahwa selama pembelajaran daring guru berusaha menciptakan pembelajaran yang menyenangkan walaupun ditengah pandemi yang mengharuskan peserta didik tetap di rumah, namun guru tetap berusaha untuk memberlakukan pembelajaran 
daring semenarik mungkin agar siswa antusias dalam mengikuti pembelajaran tersebut. Pembelajaran yang guru lakukan hampir sama seperti pembelajaran secara tatap muka pada umumnya, seperti halnya guru menyapa siswa, guru memberi semangat sebelum pembelajaran dimulai, membaca do'a dan muroja'ah terlebih dahulu sebelum belajar dan lain sebagianya. Maka artinya guru tetap menjalani pembelajaran yang semestinya disampaikan secara langsung namun bedanya kegiatan guru dari kegiatan pendahuluan sampai kegiatan penutup direkam kedalam video dan pola pembelajaran yang guru lakukan dapat disesuaikan dengan pembelajaran daring, tujuannya siswa dapat melihat dan penyimak penjelasan guru seperti di kelas. Walaupun pada pembelajaran daring tetap memiliki kekurangan dibanding pembelajaran secara langsung.

Rusman (2015:22) mengungkapkan bahwa pembelajaran pada dasarnya yaitu suatu proses interaksi antara siswa dan guru, guru dan siswa yang dilakukan secara langsung tatap muka ataupun tidak secara langsung yang dibantu dengan media pembelajaran. Hal tersebut disadari karena perbedaan interaksi, maka kegiatan pembelajaran bisa dilakukan dengan variasi/pola pembelajaran lain. Lalu kemudian didukung pula oleh pendapat Rusman (2015:145-146) fungsi pembelajaran teamtik yaitu salah satunya siswa dapat memahami pelajaran lebih mendalam dan berkesan, siswa memiliki semangat belajar yang tinggi sebab siswa berkomunikasi dalam kondisi yang nyata yaitu dengan bercerita, menulis, bertanya dan mempelajari bidang studi lainnya, pembelajaran lebih terkesan bermakna dan bermanfaat karena materi yang disuguhkan dalam bentuk tema dan subtema yang jelas. Maka dapat dikatakan bahwa guru melaksankan kegaitan pembelajaran sedemikian rupa agar pembelajaran daring tetap berjalan dengan baik, tetap menyenangkan dan tidak terkesan membosankan bagi peserta didik dan memberikan perubahan baik dalam diri siswa.
Sebab dalam belajar merupakan proses usaha untuk memperoleh perubahan tingkah laku secara menyeluruh (Slameto, 2003) dalam (Jamaludin, 2020: 16).

Selain guru mempersiapkan pembelajaran, guru juga memastikan perangkat komunikasi siswa, tujuannya agar siswa dapat terhubung atau bekomunikasi jarak jauh dengan guru melalui aplikasi di handphone agar apa yang ingin disampaikan guru tersampaikan kepada siswa. Jika siswa dan guru dapat menghubungi satu sama lain melalui perantara orang tua siswa, maka dengan mudah pembelajaran daring di lakukan oleh kedua belah pihak. Seperti halnya guru menghimbau siswa untuk memastikan sinyal karena akan dimulainya pembelajaran daring dan guru memberitahu notifikasi tugas kepada orang tua siswa melalui grup di aplikasi WhatsApp. Sependapat bahwa komunikasi antara pendidik dan peserta didik sebuah keharusan dan memiliki hubungan yang selaras atau harmonis, maka efektif atau tidaknya komunikasi selama pembelajaran tergantung pada dua belah pihak. Akan tetapi tetaplah guru yang memegang kendali dalam segala proses pembelajaran dan seberapa efektif komunikasi selama pembelajaran yang guru dan siswa lakukan. Efektif atau tidaknya komunikasi dapat ditinjau dari pesan atau materi yang disampaikan guru, dapat dipahami siswa dan mengeluarkan output yang positif bagi siswa (Masdul, 2018:5-6). Dengan menjalin komunikasi yang baik antara guru, siswa dan orang tua siswa maka tidak akan terjadi miskomunikasi antar sesama.

Seiring berjalannya interkasi antara guru dan siswa selama pembelajaran daring melalui perangkat komunikasi, guru pun tidak lepas membangun pemahaman siswa walaupun pembelajaran dilakukan secara daring, namun guru tetap harus memberikan pemahaman kepada siswa agar tujuan pembelajaran dapat tercapai selama siswa duduk di kelas IV. Guru kelas IV sendiri membangun pemahaman siswa dengan cara membiasakan siswa belajar sebelum mengikuti pembelajaran daring, guru 
menggunakan media pembelajaran, menyampaikan materi dengan jelas, menanyakan pemahaman kepada siswa lewat orang tuanya dan sebagainya. Menurutnya Pembelajaran yaitu sebuah rangkaian kegiatan penyampaian ilmu pengetahuan di dalam ruangan maupun luar ruangan yang dimonitori oleh guru serta didukung oleh sumber belajar dan perangkat lainnya. Warsita dalam (Rusman, 2015:21) juga mengungkapkan Pembelajaran bagian dari usaha guru membentuk dan membuat peserta didik berkecimpung dalam kegiatan pembelajaran.

Dalam membangun pemahaman siswa, guru juga dapat menstimulus keaktifan siswa dalam pembelajaran tematik berbasis daring agar kepercayaan diri siswa turut tertanam dalam diri setiap peserta didik, pengetahuan serta keterampilan siswa dapat diasah. Pada pembelajaran tematik, siswa diminta untuk aktif dalam pembelajaran. Pemaparan di atas, berhubungan dengan pendapat yang diungkapkan oleh Abdul Majid (2014: 80) pembelajaran tematik merupakan pembelajaran yang mengembangkan pengetahuan dan keterampilan anak secara simultan. Yang artinya pembelajaran tematik memberi stimulus kepada siswa untuk mengembangkan ilmu pengetahuan serta keterampilan yang dimiliki. Hal itu sesuai dengan pendapat Rusman (2015:152-153) pembelajaran tematik menekankan dan mengarahkan keterlibatan siswa untuk aktif dalam kegiatan pembelajaran. Keaktifan dalam hal pembelajaran yang guru kelas IV Salman ungkapakan, seperti siswa bebas mengungkapkan pendapat/ide, siswa aktif bertanya dan guru memancing agar siswa mau bertanya, guru menggali pengetahuan dan pengalaman awal siswa karena pada pembelajaran tematik siswa akan belajar pengetahuan secara bermakna, autentik, menyeluruh (holistik) dan aktif. Maka dari itu, dapat dijelaskan bahwa pembelajaran tematik tidak hanya melaksanakan pembelajaran semata, namun siswa diajak berfikir berdasarkan pengalaman dan kenyataan yang ada, belajar secara menyeluruh dan berkaitan dengan ilmu studi lainnya sehingga pembelajaran terkesan bermakna dan menuntut siswa untuk aktif di dalam pembelajaran. Walaupun pembelajaran yang dilakukan secara daring, guru tetap bisa menstimulus keaktifan siswa dengan cara membuka sesi tanya jawab secara personal chat, menguji pemahaman siswa dengan tanya jawab dapat berupa soal maupun pertanyaaan di google foam/quiz online.

Setelah melakukan pembelajaran guru akan memberikan evaluasi kepada siswa untuk melihat seberapa paham akan materi yang telah disampaikan guru kepada siswa dan guru mempersiapkan perangkat evaluasi untuk diujikan kepada siswa. Evaluasi yang guru berikan dapat berupa soal latihan maupun (praktik) keterampilan. Setiap kali guru memberi materi, dilanjutkan guru memberi soal latihan kepada siswa, untuk materi yang berkaitan dengan keterampilan, maka siswa diberi tugas keterampilan seperti, praktik/simulasi menari, membuat media telepon dari kaleng dan sebagainya. Tahap evaluasi yang guru kelas IV Salman lakukan tidak hanya memberikan soal latihan/tugas praktik, namun guru juga memberikan kesempatan kepada siswa untuk mengulas secara bersama-sama apa yang telah dipelajari, guru memberikan pujian kepada siswa yang sudah selesai mengumpulkan tugas, guru memberi arahan agar siswa percaya diri dalam menyelesaikan tugas, guru memberi masukan kepada siswa untuk tidak perlu merasa malumalu, dan lain sebagainya. Penilaian sikap yang guru kelas IV Salman lakukan yaitu melalui jurnal dan pengamatan melalui orang tua di grup via WhatsApp, sedangkan penilaian pengetahuan yang guru lakukan melalui soal latihan dan penugasan dan penilaian keterampilan sendiri guru menggunakan tugas praktik.

Hal tersebut sesuai dengan pendapat Rusman (2015:271-290) yaitu penilaian sikap bisa dilihat melalui observasi yang dilakukan guru terhadap siswa, menilai diri, penilaian 
sesama teman dan jurnal. Guru IV Salman menggunakan penilaian jurnal dikarnakan selama pembelajaran daring dalam memantau kegiatan yang dilakukan siswa selama belajar di rumah dan kegiatan ibadah sehari-hari siswa. Jurnal adalah sebuah catatan siswa yang berisikan informasi terkait sikap atau perilaku yang telah dilakukan di luar kelas maupun dalam kelas. Kelebihan jurnal yaitu catatan harus dilakukan sesegera mungkin, sedangkan kelemahan jurnal yaitu membutuhkan waktu terus menerus dan kesabaran untuk menuliskannya. Dalam penilaian pengetahuan sendiri terdapat tes tulis, tes lisan, penugasan. Untuk pembelajaran daring guru IV Salman menggunakan penugasan untuk mengevaluasi siswa. Penugasan merupakan penilaian kepada siswa yang diberikan sebagai tugas rumah secara individu ataupun kelompok sesuai dengan karakteristik tugas yang diberikan. Instrumen penilaian tertulis harus dilihat dari pedoman penskoran yang sudah dibuat guru. Penilaian keterampilan dapat dilakukan dengan cara praktik/unjuk kerja, portofolio, proyek. Penilaian yang guru kelas IV Salman lakukan khususnya untuk penilaian keterampilan yaitu dengan cara praktik yang dimana siswa diminta untuk mempraktikkan keterampilan/pengetahuan yang guru tugaskan, contohnya menari, membuat media telepon, dan lain-lain. Guru juga menggunakan jurnal sebagai bentuk evaluasi kepada siswa yang berisikan terkait sikap, kegiatan yang siswa lakukan selama di rumah dan ibadah seharihari siswa di rumah. Kemudian untuk penilaian pengetahuan guru menggunakan tes lisan untuk menguji hafalan/muraja'ah siswa, tes tulis, Penugasan yang guru berikan kepada siwa seperti bentuk soal latihan yang disampaikan melalui aplikasi WhatsApp/google foam.

Kemudian disamping itu juga guru memberi pujian kepada siswa, dalam pembelajaran daring biasanya guru memberi pujian lewat tulisan maupun emoticon setelah siswa menyelesaikan tugas. Pujian yang diberikan guru kepada siswa akan memberikan dampak positif bagi siswa dalam mengikuti pembelajaran, dikarenakan hal tersebut akan berpengaruh terhadap tercapaianya kompetensi. Contohnya, jika siswa dapat menjawab pertanyaan yang guru berikan, guru memberi pujian seperti, bagus, anak pintar, hebat dan lain-lain (Rahman, 2016:49-50). Kata pujian dapat memberi efek psikologi kepada siswa, sebab sentuhan pujian membuat siswa merasa dihargai atas apa yang telah dilakukan siswa dan sebagai bentuk motivasi yang dapat memberikan perubahan lebih pada ranah afektif, kognitif dan psikomotor (Djamarah dalam Rahman, 2016:50). Dengan guru memberikan pujian kepada siswa, secara tidak langsung siswa dengan sendirinya terbangun motivasi dalam diri, menjadi pribadi yang aktif dalam mengikuti pembelajaran dan semangat belajar. Tidak hanya pujian yang guru berikan, guru juga perlu memberi perhatian kepada peserta didik yang belum cukup aktif atau masih kurang percaya diri dalam mengerjakan tugas yang bersifat praktik maupun non praktik. Guru kelas IV Salman terus memberi motivasi kepada siswa khususnya bagi siswa yang merasa malu-malu mengirimkan tugas keterampilan, seperti praktik menari. Motivasi yang guru berikan agar siswa merasa percaya diri atas apa yang dikerjakan dan terus melawan rasa takut yang ada dalam diri siswa. menurut Sardiman A. M (2014) guru berperan sebagai motivator yang dimana dapat menumbuhkan semangat dan pengembangan dalam proses pembelajaran. Guru memberi dorongan agar siswa aktif dan dapat menumbuhkan kreativitas yang dimiliki. Dapat dijelaskan bahwa motivasi yang guru berikan sangat penting dan berpengaruh bagi psikologi dan kemauan siswa, karena dengan cara tersebut siswa akan timbul rasa percaya diri dalam dirinya.

\section{Dampak Karakter Percaya Diri Siswa Melalui Proses Pembelajaran Tematik Secara Daring}

Kepercayaan diri siswa dapat digambarkan melalui perubahan tingkah laku siswa selama pembelajaran daring, karakter 
percaya diri siswa tidak lepas dari peranan guru dalam proses pembelajaran. Berbagai cara yang guru lakukan agar siswa mencapai kompetensi yang sudah ditentukan. Percaya diri siswa dapat terlihat ketika siswa aktif mengikuti proses demi proses pembelajaran. Selama pembelajaran daring siswa lebih aktif seperti menanyakan materi yang kurang dipahami, tangkap dan sigap mengerjakan tugas yang diberikan guru, walaupun ada siswa yang sedikit terlambat mengerjakan tugas karena menunggu hanphone dan dampingan orang tua, namun guru tetap menunggu siswa sampai selesai mengerjakaran tugas. Walaupun masih ada siswa yang merasa kurang percaya diri dalam mengerjakan tugas khususnya tugas keterampilan, namun guru tetap memberikan arahan kepada siswa. Menurut Mulyasa (2002) dalam Wibowo (2016:130) mengemukakan bahwa pembelajaran dapat disebut berhasil jika seluruh atau sebagian besar siswa aktif secara fisik, mental, psikis ataupun sosial dalam kegiatan pembelajaran. Maka dapat dikatakan pembelajaran daring yang dilakukan guru merupakan usaha guru agar siswa aktif dalam kegiatan pembelajaran, aktif secara non fisik ataupun fisik sehingga pembelajaran dapat dilakukan secara bermakna dan tetap kondusif.

Selanjutnya siswa menjadi lebih komunikatif, dilihat dari pembelajaran daring yang siswa dan guru lakukan yaitu siswa tidak sungkan berkomunikasi dengan guru terkait apapun disertai dengan bahasa yang sopan, kalaupun ada siswa yang menggunakna bahasa yang kurang sopan, guru akan mengingatkan siswa lewat orang tuanya atau mengungkapkan langsung kepada siswa via aplikasi WhatsApp. Siswa yang leluasa berkomunikasi dengan guru maupun temannya, siswa tersebut difasilitasi handphone oleh orang tuanya selama di rumah. Siswa berkomunikasi aktif sebab pembelajaran tematik yang menuntut siswa untuk berkomunikasi dengan keadaan yang nyata. Berdasarkan pernyataan di atas, berkesinambungan dengan pendapat Rusman (2015:145-146) yang menyatakan bahwa tujuan dan fungsi pembelajaran tematik salah satunya yakni siswa memiliki semangat belajar yang tinggi sebab siswa berkomunikasi dalam kondisi yang nyata yaitu dengan bercerita, menulis, bertanya dan mempelajari bidang studi lainnya. Dalam proses pembelajaran juga akan terjadi proses komunikasi berupa penyampaian pesan dari guru kepada penerima pesan yaitu siswa itu sendiri, hal tersebut memiliki tujuan bahwa apa yang disampaikan dapat memberikan pemahaman, pengaruh dan perubahan sikap yang lebih baik. Maka pembelajaran dapat dikatakan berhasil dan berjalan lancar jika komunikasi yang terjalin selama pembelajaran cukup efektif (Masdul, 2018:3). Dengan demikian siswa cenderung aktif berkomunikasi dengan guru terkait kepentingan pembelajaran dan tugas yang guru berikan. Dengan adanya komunikasi yang aktif antara guru dan siswa, menjadikan siswa semakin percaya diri atas apa yang telah dilakukan dan tidak merasa malu-malu dan lebih terbuka kepada guru.

Siswa mudah bersosialisasi, bagian dari tanda siswa yang memiliki percaya diri. Siswa yang mudah bersosialisasi dengan siapapun dan dimanapun akan menjalin komunikasi terkait apa yang ingin siswa ungkapkan dan tanyakan kepada orang lain, teman, tetangga dan sebagainya. Guru kelas IV mengungkapkan bahwa siswa dapat bersosialisasi dengan temannya walaupun jarak jauh menggunakan perangkat komunikasi, siswa juga dapat bersosialisasi dengan orang-orang disekitar rumahnya. Iswidharmanjaya dan Enterprise (2014: 49) menyebutkan bahwa salah satu ciri-ciri orang yang percaya diri yaitu mereka yang mudah bergaul dan dapat menyesuaikan diri pada lingkungan baru. Namun hal tersebut tergantung kepada orang tuanya, jika orang tuanya membebaskan siswa untuk bersosialisasi dengan orang sekitar tempat tinggalnya atau dengan teman sekolahnya semua tergantung pada orang tua. Namun yang guru tahu siswa-siswanya dapat bersosialisasi dengan teman sebayanya dan aktif berkomunikasi dengan guru, sehingga guru 
percaya bahwa siswanya dapat bersosialisasi atau berbaur dengan baik terhadap orang-orang disekelilingnya.

Kemudian siswa yang memiliki karakter percaya diri dapat dilihat dari kepribadiannya apakah cenderung murung atau ekspresif dalam menyikapi sesuatu. Guru kelas IV Salman sendiri menyampaikan bahwa siswa yang sudah tertanam karakter percaya diri, terlihat berekspresi secara positif dalam menyikapi sesuatu tidak merasa malu-malu dalam mengungkapkan pendapat ataupun bertanya, lebih tenang dan enjoy. Orang yang percaya diri memiliki ciri-ciri yaitu bersikap tenang, tidak mudah cemas dan optimis (Iswidharmanjaya dan Enterprise, 2014:49) kemudian dilanjutkan menurutnya, bagi orang yang percaya diri mampu bersikap positif, menerima diri apa adanya, dapat berinteraksi baik dengan orang lain. Siswa juga tidak merasa kaku dalam bersikap terhadap guru, seperti apa adanya. Bagi siswa yang merasa masih malu-malu atau kurang percaya diri, guru tetap memberi nasihat, arahan lewat orang tua siswa agar siswa terus termotivasi. Perasaan takut, malu, tidak percaya diri siswa akan telapas dari diri siswa dari waktu ke waktu. Yang terpenting guru dan orang tua tetap memberikan dorongan dan motivasi kepada siswa.

\section{SIMPULAN DAN REKOMENDASI}

$\begin{array}{llr}\text { Kemudian } & \text { setelah } & \text { peneliti } \\ \text { mendapatkan hasil lapangan, } & \text { dapat }\end{array}$
disimpulkan sebagai berikut:

A. Perencanaan guru sebelum melaksanakan kegiatan pembelajaran dalam menanamkan karakter percaya diri yaitu dengan membuat rancangan pembelajaran yang sama seperti rancangan pembelajaran pada saat di kelas atau tatap muka terdapat kompetensi inti, kompetensi dasar dan indikator pencapaian kompetensi, tujuan pembelajaran, materi pembelajaran, media pembelajaran, langkah-langkah kegiatan dan evaluasi pembelajaran. Namun rancangan yang guru buat sedikit lebih ringkas dibanding rencana pelaksanaan pembelajaran (RPP) yang guru buat secara tatap muka. Walaupun pembelajaran dilakukan secara daring, guru menyusun komponen rencana pembelajaran seperti, metode apa yang digunakan, seperti metode ceramah, penugasan. Media yang digunakan seperti video pembelajaran yang kemudian dikirim kepada siswa melalui perangkat komunikasi orang tua siswa. Kemudian langkah-langkah kegiatan pembelajaran terdapat kegiatan pembuka, inti dan penutup. Bentuk evaluasi yang guru berikan kepada siswa, seperti soal latihan, penugasan, praktik menari, jurnal ibadah harian siswa, menggunakan Google foam dan lain sebagainya. Tidak lupa guru juga menjalin komunikasi dengan orang tua siswa menggunakan aplikasi WhatsApp agar pembelajaran daring yang dilakukan antara guru dan siswa dapat berjalan dengan lancar dan kondusif. Jika guru memberi tugas kepada siswa, dikirim melalui aplikasi WhatsApp. Penanaman karakter pada siswa kelas IV sangat berkaitan dengan pembelajaran tematik yang dimana materi yang dipelajari saling bersatu padu sehingga menuntut siswa untuk aktif serta mengasah kepercayaan diri siswa, seperti halnya bertanya kepada guru, bercerita, menjawab pertanyaan guru, praktik menari, menyetor hafalan dan lain-lain. Dengan begitu seiring siswa mengikuti pembelajaran, siswa juga dipersiapkan menjadi pribadi yang memiliki karakter percaya diri.

B. Proses penanaman karakter percaya diri siswa melalui pembelajaran tematik secara daring, Guru berusaha menciptakan pembelajaran yang menyenangkan walaupun ditengah pandemi yang mengharuskan peserta didik tetap di rumah. Namun guru tetap berusaha untuk memberlakukan pembelajaran daring semenarik mungkin dengan cara guru 
menyampaikan materi dalam bentuk video pembelajaran sehingga siswa dapat menyimak penjelasan guru, siswa dapat mencari atau menambah wawasan pengetahuan melalui internet, siswa dapat berkomunikasi dengan guru secara personal chat untuk bertanya kepada guru terkait materi yang belum dipahami ataupun mengumpulkan tugas. Hal tersebut dilakukan oleh guru agar siswa antusias dalam mengikuti pembelajaran tersebut. Pembelajaran yang guru lakukan hampir sama seperti pembelajaran secara tatap muka pada umumnya namun dikemas dalam bentuk video pembelajaran, seperti halnya guru menyapa siswa, guru memberi semangat sebelum pembelajaran dimulai, membaca do'a dan muroja'ah terlebih dahulu sebelum belajar dan lain sebagianya. Proses yang guru lakukan dalam menanamkan karakter percaya diri selama pembelajaran daring dengan cara guru memberi tugas keterampilan pada siswa yang menguji kepercayaaan diri siswa, seperti guru memberi tugas praktik menari, guru menguji atau muroja'ah hafalan surah dengan cara video call atau divideokan oleh orang tua siswa di rumah, guru memberi kesempatan kepada siswa untuk bertanya terkait pembelajaran secara daring melalui media komunikasi WhatsApp yang didampingi oleh orang tua masing-masing ataupun siswa sendiri yang bertanya kepada guru. Guru juga membangun pemahaman siswa dengan memfasilitasi media yang menunjang kemudahan siswa dalam memahami pelajaran dengan cara memberikan video pembelajaran, guru menstimulus keaktifan siswa selama pembelajaran daring, seperti memancing siswa untuk bertanya, guru memberikan kesempatan kepada siswa untuk menyimpulkan materi dan pada akhir pembelajaran guru mengevaluasi materi melalui pemberian tugas, soal latihan ataupun praktik dan sikap siswa salah satunya dengan cara memberi pujian dengan mengirimkan emoticon ataupun pujian dalam bentuk tulisan, adapun arahan dan nasihat yang diberikan guru kepada siswa sehingga percaya diri siswa mengalami perkembangan menjadi lebih baik.

Karakter percaya diri siswa melalui proses pembelajaran tematik secara daring yaitu dapat digambarkan melalui perubahan tingkah laku siswa selama pembelajaran daring, karakter percaya diri siswa tidak lepas dari peranan guru dalam proses pembelajaran. Percaya diri siswa dapat terlihat ketika siswa aktif mengikuti proses demi proses pembelajaran. Selama pembelajaran daring siswa lebih aktif seperti menanyakan materi yang kurang dipahami, tangkap dan sigap mengerjakan tugas yang diberikan guru. Selanjutnya siswa menjadi lebih komunikatif, dilihat dari pembelajaran daring yang siswa dan guru lakukan yaitu siswa tidak sungkan berkomunikasi dengan guru melalui media komunikasi terkait apapun disertai dengan bahasa yang sopan. Siswa mudah bersosialisasi, bagian dari tanda siswa yang memiliki percaya diri yaitu siswa dapat bermain dengan teman sebayanya, siswa mudah berinterksi dengan teman-temannya, siswa mudah bersosialisasi dengan siapapun dan dimanapun akan menjalin komunikasi terkait apa yang ingin siswa ungkapkan dan tanyakan kepada orang lain, teman, tetangga dan siswa dapat mengekspresikan sesuatu dengan cara bertingkah laku positif seperti mengungkapkan dengan jujur apa yang ingin siswa ungkapkan kepada guru dan dapat dilihat dari antusiasme siswa dalam bertanya kepada guru.

\section{DAFTAR PUSTAKA}

Alsa, A. (2006). Hubungan Antara Dukungan Sosial Orang Tua dengan Kepercayaan Diri Remaja Penyandang Cacat Fisik pada SLB-D YPAC. Jurnal Psikologi Proyeksi, 1(3), 12-20. 
Fathorrahman. (2017). Kompetensi Pedagogik, Kepribadian dan Kompetensi Sosial Dosen. Akademika, 15.

Feralys, M. N. (2015). Kompetensi Guru dalam Peningkatan Prestasi Belajar pada SMP Negeri dalam Kota Banda Aceh. Jurnal Administrasi Pendidikan Pascasarjana Universitas Syiah Kuala, 3, 1-9.

Ghufron, N., \& Risnawita, R. (2010). TeoriTeori Psikologi. Yogyakarta: Ar-Ruzz Media Group.

Hidayati, L. (2018). Peran Guru dalam Mengembangkan Rasa Percaya Diri Anak Usia Dini di Kelompok A RA Bintang Kecil Ketanggungan, Wirobrajan, Yogyakarta.

Hosnan, M. (2016). Etika Profesi Pendidik. Bogor: Ghalia Indonesia.

Hosnan, M. (2016). Pendekatan Saintifik dan Kontekstual dalam Pembelajaran Abad 21. Bogor: Ghalia Indonesia.

Iswidharmanjaya, D. (2014). Satu Hari Menjadi Lebih Percaya Diri. Jakarta: PT Elex Media Komputindo.

Jamaludin, U. (2020). Pembudayaan Nilai Budaya Sekolah Berbasis Islam pada Pembelajaran Ilmu Pengetahuan Sosial.

Jamaludin, U., \& Rachmatullah, R. (2018). Pembelajaran Pendidikan IPS (Teori Konsep dan Aplikasi bagi Guru dan Mahasiswa. Bekasi: CV. Nurani.

Koswara., \& Rasto. (2016). Kompetensi dan Kinerja Guru Berdasarkan Sertifikasi Profesi. Jurnal Pendidikan Manajemen Perkantoran, 1(3), 12-20.

Lickona, T. (2012). Character Matters. Jakarta: Bumi Aksara.

Majid, A. (2014). Pembelajaran Tematik Terpadu . Bandung: PT. Remaja Rosdakarya.

Majid, A., \& Andayani, D. (2012). Pendidikan Karakter Perspektif Islam. Bandung: PT. Rosdakarya.
Masdul, M. (2018). Komunikasi Pembelajaran. Iqra Jurnal Kependidikan dan Keislaman, 1.

Moloeng, L. (2012). Metodologi Penelitian Kualitatif. Bandung: PT. Remaja Rosdakarya.

Moloeng, L. (2017). Metodologi Penelitian Kualitatif. Bandung: PT. Remaja Rosdakarya.

Muslich, M. (2009). Sertifikasi Guru Menuju Profesionalisme Pendidik. Jakarta: PT. Bumi Aksara.

Mustari, M. (2014). Nilai Karakter Refleksi Untuk Pendidikan . Jakarta: PT. RajaGrafindo Persada.

Narwanti, S. (2014). Pendidikan Karakter. Yogyakarta: Familia Pustaka Keluarg.

Nora, T., Suntoro, I., \& Yanzi, H. (2017). Peranan Guru dalam Menanamkan Rasa Percaya Diri Siswa di SMP PGRI 2 Bekri. Jurnal Kultur Demokrasi, 5.

Pamungkas, W. (2019). Pengamatan Data Meteorologi Untuk Keselamatan Navigasi di Pelayaran Saat Kondisi Cuaca Buruk.

Permendikbud No. 22 Tahun 2016. (2019).

Perpres No. 87 Tahun 2017. (2019).

Puspitarini, H. (2013). Membangun Rasa Percaya Diri pada Anak. Jakarta: PT. Elex Media Komputindo.

Rahman, A. (2016). Tutur Pujian Guru dalam Interaksi Pembelajaran di Kelas. Lingua, 13.

Rusman. (2014). Model-Model Pembelajaran Mengembangkan Profesionalisme Guru. Jakarta: PT. Rajagrafindo Persada.

Rusman. (2015). Pembelajaran Tematik Terpadu Teori, Praktik dan Penilaian. Depok: PT. Rajagrafindo Persada.

Sagala, S. (2011). Kemampuan Profesional Guru dan Tenaga Kependidikan. Bandung: CV. Alfabeta.

Sardiman , M. (2014). Interaksi dan Motivasi Belajar Mengajar. Jakarta: PT. Rajagrafindo Persada. 
Sardiman, M. (2009). Interaksi dan Motivasi Belajar Mengajar. Jakarta: PT. Rajagrafindo Persada.

Satori, D. (2015). Profesi Keguruan dalam Mengembangkan Siswa. Jakarta: Universitas Terbuka.

Sudardjo, S., \& Esti, P. H. (2003). Kepercayaan Diri dan Kecemasan Komunikasi Interpersonal pada Mahasiswa. Jurnal Psikologi, 2, 6771.

Sugiyono. (2013). Metode Penelitian Kuantitatif Kualitatif dan $R \& D$. Bandung: CV. Alfabeta.

Sugiyono. (2014). Metode Penelitian Pendidikan Pendekatan Kuantitatif Kualitatif dan $R \& D$. Bandung: CV. Alfabeta.

Sugiyono. (2015). Metode Penelitian Pendidikan (Pendekatan Kuantitatif, Kualitatif dan R\&D). Bandung: CV. Alfabeta.

Taufik, M. (2013). Pengantar Pendidikan. Tangerang: CV. Mujahid Press.

UU Republik Indonesia No. 14 Tahun 2005. (2019).

UU Republik Indonesia No. 20 Tahun 2003. (2019).

Wibowo, N. (2016). Upaya Peningkatan Keaktifan Siswa Melalui Pembelajaran Berdasarkan Gaya Belajar di SMK Negeri 1 Saptosari. Jurnal Electronic, Informatics, and Vocational Education (ELINVO), 1. 